\title{
STRATEGI MEMPERTAHANKAN USAHA PEDAGANG KAKI LIMA (PKL) DI MASA PANDEMI COVID19
}

\author{
Hanna Zulhijahyanti ${ }^{1}$, Kintan Ayu Agnes Safira ${ }^{2}$, Leonita Lisha Saputri ${ }^{3}$, \\ Erwin Permana ${ }^{4}$ \\ Universitas Pancasila, Jakarta \\ E-mail: ${ }^{1}$ hannazy21@gmail.com; ${ }^{2}$ leonitalsha@gmail.com; \\ 3kintanayuagnessafiraa@gmail.com; ${ }^{3}$ erwin.permana@univpancasila.ac.id
}

\begin{abstract}
ABSTRAK
Salah satu pelaku Usaha Mikro dan Kecil sektor informal yang merasakan dampak signifikan dari pandemi Covid-19 adalah Pedagang Kaki Lima (PKL). Penelitian ini bertujuan untuk menjelaskan strategi bisnis pedagang kaki lima agar mampu mempertahankan kelangsungan hidupnya dalam usaha-usaha yang akan dilakukan (PKL) di masa pandemi covid-19. Penelitian ini termasuk dalam penelitian kualitatif. Dari hasil penelitian, Strategi pemasaran yang digunakan Pedagang kaki lima di tengah pandemi covid-19 yaitu dengan menggunakan media sosial, antara lain, facebook, instagram, Whatsapp, telegram, serta tergabung dalam usaha online lainnya seperti shopee, go-food, dan grap-food. Dengan menggunakan media sosial pembeli dan pedagang dengan mudahnya melakukan transaksi tanpa harus bersentuhan. maka dapat diuraikan bahwa strategi bertahan dapat berjalan sesuai dengan yang diharapkan dengan memperhatikan daya beli konsumen di masa pandemi covid-19 ini.
\end{abstract}

Kata kunci : Covid19, Pedagang Kaki Lima, Strategi

\section{ABSTRACT}

One of the informal sector Micro and Small Business actors who feel the significant impact of the Covid-19 pandemic is street vendors (PKL). This study aims to explain the business strategy of street vendors in order to be able to maintain their survival in the businesses that will be carried out (PKL) during the Covid-19 pandemic. This research is included in qualitative research. From the results of the research, the marketing strategy used by street vendors in the midst of the Covid-19 pandemic is by using social media, including Facebook, Instagram, Whatsapp, telegram, and joining other online businesses such as shopee, go-food, and grapfood. By using social media, buyers and traders can easily make transactions without having to touch. it can be explained that the survival strategy can work as expected by paying attention to the purchasing power of consumers during the Covid-19 pandemic.

Keywords: Covid19, Street Traders, Strategy

\section{PENDAHULUAN}

Sejak akhir tahun 2019 hingga saat ini, seluruh dunia termasuk Indonesia sedang di landa virus yang mewabah yaitu virus corona atau Covid-19. Organisasi Kesehatan Dunia (World Health Organization) telah menetapkan status gawat darurat global untuk wabah virus corona. Dunia menjadi waspada akan wabah virus ini. tidak hanya waspada terhadap penyakitnya saja akan tetapi juga waspada terhadap dampak yang mungkin terjadi terhadap perekonomian dunia [1,2].

Usaha Kecil Menengah (UKM) mempunyai peranan yang penting dalam pertumbuhan ekonomi dan industri suatu negara (Husband and Purnendu, 1999; Mahemba, 2003; Tambunan, 2005). Masalah ini semakin serius, sejak ditetapkannya Pembatasan Sosial Berskala Besar (PSBB) meliputi pembatasan kegiatan penduduk di suatu wilayah yang diduga terinfeksi Covid-19 termasuk pembatasan terhadap 
pergerakan orang/barang dalam satu provinsi atau kabupaten/kota. Selain itu, penerapan physical distancing yang berarti melakukan menjaga jarak satu meter dengan manusia lain hingga Work From Home (WFH) di Indonesia membuat aktivitas masyarakat di luar ruangan menjadi berkurang. Sejak diterapkan kebijakan tersebut, mengakibatkan perekonomian menjadi melemah karena daya beli konsumen ikut menurun. Tidak sedikit pedagang yang kehilangan penghasilan dan harus gulung tikar akibat pandemi ini. Ketua umum DPP Asosiasi Pedagang Kaki Lima (APKLI), Ali Mahsun, mengungkapkan bahwa selama pandemi omzet PKL menurun hingga $80 \%$, sedangkan yang mengalami kebangkrutan sekitar $40 \%$. Pendapatan PKL baru akan berangsur membaik ketika perkantoran dan aktivitas formal lain kembali dibuka [3,4].

Menurut pemantauan ILO (International Labour Organization) karena adanya tindakan karantina penuh atau parsial saat ini sudah berdampak pada hampir 2,7 milliar pekerja, yang sudah mewakili sekitar $81 \%$ tenaga kerja dunia. BPS menyebutkan tiga faktor utama yang dihadapi oleh Usaha Mikro dan Kecil (UMK) karena pandemi dan Pembatasan Sosial Berskala Besar (PSBB) adalah penurunan permintaan yang diakibatkan oleh pelanggan/klien yang juga terdampak covid-19 $(78,35 \%)$, rekan bisnis yang terdampak mengakibatkan operasional tidak berjalan dengan baik $(56,80 \%)$, kendala keuangan atau permodalan $(62,21 \%)$. Dan sebanyak $84,20 \%$ Usaha Mikro dan Kecil (UMK) mengalami penurunan pendapatan (BPS, 2020a). Salah satu pelaku Usaha Mikro dan Kecil sektor informal yang merasakan dampak signifikan dari pandemi Covid-19 adalah Pedagang Kaki Lima (PKL). PKL menjadi kasus yang perlu diperhatikan karena PKL seringkali berada diluar pengawasan dan regulasi pemerintah karena banyak dari PKL yang tidak memiliki izin resmi.

Untuk itu perlu adanya strategi berdagang yang merupakan salah satu cara atau langkah-langkah yang dilakukan agar mampu mempertahankan kelangsungan hidupnya dalam usaha-usaha yang akan dilakukan pedagang kaki lima [5]. Peranan TI dalam berbagai aspek kegiatan bisnis dapat dipahami karena sebagai sebuah teknologi yang menitik beratkan pada pengaturan sistem informasi dengan penggunaan computer. TI dapat memenuhi kebutuhan informasi dunia bisnis dengan sangat cepat, tepat waktu, relevan, dan akurat. Kontribusi teknologi informasi (TI) dalam menciptakan nilai tambah bagi perusahaan merupakan salah satu isu kontroversial dalam bidang economy of information technology. Era digital memang tidak mungkin untuk dihindari. Pakar pemasaran Yuswohadi mengungkapkan bahwa jika ingin bertahan, maka pelaku UMKM harus mampu memaksimalkan manfaat perkembangan digital [6,7]. Dengan pesatnya perkembangan teknologi, dunia digital dan internet tentu juga berimbas pada dunia pemasaran. Tren pemasaran di dunia beralih dari yang semula konvensional (offline) menjadi digital (online). Digital marketing ini lebih prospektif karena memungkinkan para calon pelanggan potensial untuk memperoleh segala macam informasi mengenai produk dan bertransaksi melalui internet $[8,9]$. E-commerce menjadi salah satu alat yang bisa dimanfaatkan pebisnis untuk memasarkan produk dan menarik pelanggan potensial dari berbagai negara di dunia [10].

Penelitian ini bertujuan untuk menganalisis startegi bertahan PKLdimasa pandemic Covid-19. Penelitian ini menjadi penting karena kontribusi sektor informal yang cukup besar terhadap perekonomian dan penyerapan tenaga kerja. Hasil penelitian diharapkan menjadi landasan pelaku PKL untuk menjalankan bisnis dan menjaga eksistensi selama pandemik Covid-19. 


\section{TINJAUAN PUSTAKA}

Pedagang kaki lima sebagai salah satu komponen utama dari usaha mikro yang terlibat dalam usaha sektor informal, menghadapi lingkungan yang masih kurang kondusif, sehingga menjadi faktor yang menghambat eksistensi dan perkembangan bisnisnya. mengakibatkan kondisi umum pedagang kaki lima mengalami produktivitas dan daya saing yang relatif rendah [11]. Pedagang kaki lima menjadi pekerjaan yang tersedia bagi anggota masyarakat yang berpendidikan rendah dengan pengalaman serta keterampilan yang sangat terbatas [12]. Usaha kecil menjadi bagian tak terpisahkan dari kehidupan keseharian masyarakat di Indonesia maupun di belahan dunia pada umumnya. Usaha kecil sangat menunjang kemudahan hidup konsumen Indonesia dan berpengaruh sangat besar terhadap penciptaan lapangan kerja juga peningkatan pertumbuhan perekonomian suatu negara.

Tingkat penggangguran terbuka yang relatif tinggi dan pembengkakan sektor informal ditandai dengan rendahnya produktivitas dan penghasilan, yang disebabkan oleh ketidakmampuan sektor formal menyerap lebih banyak tenaga kerja karena pertumbuhan penduduk melebihi kecepatan penyediaan lapangan pekerjaan. Oleh karena itu kegiatan ekonomi sektor informal menjadi alternatif utama untuk mengurangi pengangguran.

Dalam diskusi yang digelar Pusat Studi Ekonomi dan Kebijakan Publik (PSEKP) sektor informal adalah sektor yang tidak terorganisasi (unorganized), tidak teratur (unregulated), dan kebanyakan legal tetapi tidak terdaftar (unregistered). Di Negara Sedang Berkembang, sekitar 30-70 persen populasi tenaga kerja di perkotaan bekerja di sektor informal. Sektor informal memiliki karakteristik seperti jumlah unit usaha yang banyak dalam skala kecil; kepemilikan oleh individu atau keluarga, teknologi yang sederhana dan padat tenaga kerja, tingkat pendidikan dan ketrampilan yang rendah, akses ke lembaga keuangan daerah, produktivitas tenaga kerja yang rendah dan tingkat upah yang juga relatif lebih rendah dibandingkan sektor formal.

Entrepreneurship (kewirausahaan) adalah proses membuat sesuatu yang baru dengan nilai dari konsumsi waktu dan daya yang diperlukan, memperkirakan keuangan, fisik, dan resiko sosial, dan mendapatkan penghargaan hasil dari moneter dan kepuasan personal dan kebebasan. Sehingga dapat disimpulkan bahwa entrepreneurship adalah kemampuan untuk melihat, mengelola dan menentukan keputusan pada setiap peluang dan memanfaatkannya sehingga mampu meningkatkan taraf hidup dimasa depan [13].

Strategi bisnis yang tepat untuk memasarkan produk di masa pandemi covid19 ini adalah melalui media elektronik dimana antara produsen dan konsumen tidak bertemu langsung pada satu tempat tetapi memiliki jangkauan pemasaran yang sangat luas $[14,15]$. Strategi Bertahan (Survival Strategy) adalah pola-pola berbagai usaha yang direncanakan olehmanusia untuk dapat memenuhi syarat minimal yang dibutuhkannya dan untuk memecahkan masalah-masalah yang mereka hadapi di situ. Pola-pola disini adalah pola-pola perilaku atau tindakan.

Dunia bisnis di era globalisasi, pemasaran produk baik barang maupun jasa dapat memanfaatkan kemajuan teknologi informasi. Media sosial merupakan produk dari teknologi informasi memberikan manfaat optimal bagi pelaku usaha. Dengan media sosial pelaku usaha dapat memaparkan spesifikasi produk, kualitas, dan harga sehingga konsumen dapat lebih leluasa memilih barang yang dibutuhkan sesuai dengan kemampuannya $[14,15]$.

E-Commerce (perniagaan elektronik) adalah suatu jenis dari mekanisme bisnis secara elektronik yang memfokuskan diri pada transaksi bisnis berbasis individu dengan menggunakan internet (teknologi berbasis jaringan digital) sebagai medium pertukaran barang atau jasa baik antara dua buah institusi (business to business) dan 
konsumen langsung (business to consumer), melewati kendala ruang dan waktu yang selama ini merupakan hal-hal yang dominan. Dengan aplikasi e-commerce, hubungan antar perusahaan dengan entitas eksternal lainnya (pemasok, distributor, rekanan, konsumen) dapat dilakukan secara lebih cepat, lebih intensif, dan lebih murah daripada aplikasi prinsip manajemen secara konvensional (door to door, one-to-one relationship) [14].

Menurut Dave Chaffey, digital marketing merupakan atau pemasaran digital memiliki arti yang hampir sama dengan pemasaran elektronik (e-marketing) keduanya menggambarkan manajemen dan pelaksanaan pemasaran menggunakan media elektronik, jadi yang dimaksud digital marketing adalah penerapan teknologi digital yang membentuk saluran online (channel online) ke pasar (website, e-mail, database, digital TV dan melalui berbagai inovasi terbaru lainnya termasuk di dalamnya blog, feed, podcast, dan jejaring sosial) yang memberikan kontribusi terhadap kegiatan pemasaran yang bertujan untuk mendapat keuntungan serta membangun dan mengembangkan hubungan dengan pelanggan selain itu mengembangkan pendekatan yang terencana untuk meningkatkan pengetahuan tentang konsumen (terhadap perusahaan, perilaku, nilai dan tingkat loyalitas terhadap merek produknya), kemudian menyatukan komunikasi yang ditargetkan dengan pelayanan online sesuai kebutuhan masing-masing individu atau pelanggan yang spesifik. Singkatnya digital marketing adalah mencapai tujuan pemasaran melalui penerapan teknologi dan media digital, khususnya internet [16].

\section{METODOLOGI PENELITIAN}

Jenis penelitian ini menggunakan Metode Penelitian Kualitatif. Metode penelitian kualitatif adalah metode penelitian yang berlandaskan pada filsafat postpositivisme, digunakan untuk meneliti pada kondisi objek yang alamiah, (sebagai lawannya adalah eksperimen) dimana peneliti adalah sebagai instrumen kunci, teknik pengumpulan data dilakukan secara triangulasi (gabungan), analisis data bersifat induktif/kualitatif, dan hasil penelitian kualitatif lebih menekankan makna dari pada generalisasi.

Penelitian kualitatif dilaksanakan untuk membangun pengetahuan melalui pemahaman dan penemuan. Pendekatan penelitian kualitatif adalah suatu proses penelitian dan pemahaman yang berdasarkan pada metode yang menyelidiki suatu fenomena social dan masalah manusia. Pada penelitian ini peneliti membuat suatu gambaran kompleks, meneliti kata-kata, laporan terinci dari pandagan responden dan melakukan studi pada situasi yang alami. Dalam penelitian kualitatif, peneliti adalah instrumen kunci. Oleh karena itu, peneliti harus memiliki bekal teori dan wawasan yang luas jadi bisa bertanya, menganalisis, dan mengkonstruksi objek yang diteliti menjadi lebih jelas. Penelitian ini lebih menekankan pada makna dan terikat nilai.

Penelitian kualitatif digunakan jika masalah belum jelas, untuk mengetahui makna yang tersembunyi, untuk memahami interaksi social, untuk mengembangkan teori, untuk memastikan kebenaran data dan meneliti sejarah perkembangan.

Sumber data pada penelitian ini menggunakan sumber data sekunder. Data sekunder yaitu data yang telah dikumpulkan untuk maksud selain menyelesaikan masalah yang sedang dihadapi. Data ini dapat ditemukan dengan cepat. Dalam penelitian ini yang menjadi sumber data sekunder adalah literatur, artikel, jurnal serta situs di internet yang berkenaan dengan penelitian yang dilakukan.

\section{Hasil Pembahasan}

Dengan adanya virus covid-19 yang sudah menyebar luas ke seluruh dunia termasuk Indonesia berimbas pada permasalahan perekonomian Indonesia terutama 
UKM Sektor Informal Pedagang Kaki Lima. Mengacu pada data perkembangan Covid 19, Terhitung dari tanggal 11 Juli 2020 sebanyak 216 negara dengan 12.237 .085 jiwa yang terkonfirmasi positif corona, sedangkan yang terjadi di indonesia sudah menyentuh angka diatas lima puluh ribu yaitu sebesar 74.018 jiwa yang terdeteksi positif corona (Satgas Covid-19, 2020).

Semenjak beberapa daerah memberlakukan pembatasan pergerakkan orang, kerumunan sampai ada yang melakukan karantina parsial, salah satu sektor informal yaitu pedagang kaki lima mengalami kerugian karena pembeli sangat jarang bahkan tak ada sama sekali. Data riset Kementerian Koperasi dan UKM, melaporkan UMKM yang terdiri dari pedagang besar dan pedagang kaki lima mengalami dampak pandemi Covid-19 yang paling tinggi (40,92\%), disusul UMKM penyedia akomodasi, makanan minuman sebanyak $(26,86 \%)$ dan yang paling kecil terdampak adalah industri pengolahan sebanyak $(14,25 \%)$.

Menyikapi kondisi ini, PKL harus memiliki strategi bertahan hidup untuk menghadapinya. Istilah strategi bertahan hidup diambil dari konsep livelihood strategies yang dikemukakan (Chaudhuri, 2018), yaitu cara rumah tangga untuk memperoleh pendapatan dengan mengoptimalkan berbagai sumber daya yang dimiliki sehingga dapat menghasilkan sesuatu yang bernilai ekonomis. Untuk itu perlu adanya strategi berdagang yang merupakan salah satu cara atau langkah-langkah yang dilakukan agar mampu mempertahankan kelangsungan hidupnya dalam usaha-usaha yang akan dilakukan pedagang kaki lima [17].

Berbagai strategi bertahan hidup biasanya dilakukan oleh masyarakat rentan perkotaan dalam masa krisis, seperti nafkah ganda, pengurangan kuantitas barang yang dikonsumsi atau dengan cara menambah penghasilan melalui pekerjaan sampingan atau bekerja di sektor informal [17]. Salah satu strategi yang dapat dilakukan oleh pelaku usaha kecil seperti pedagang kaki lima adalah melakukan transformasi usaha secara online (e-commerce). Usaha online memiliki pengaruh signifikan dalam meningkatkan aspek pemasaran dan pendapatan pelaku usaha. Akan tetapi, tidak semua pelaku usaha informal memiliki kemampuan adaptasi dengan iklim usaha online, karena keterbatasan sumber daya pada pelaku usaha informal, seperti keterampilan rendah dan teknologi sederhana.

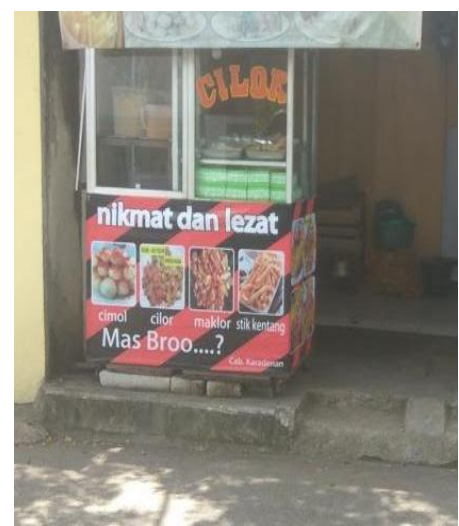

Gambar 1. Cilor Mas Broo Offline

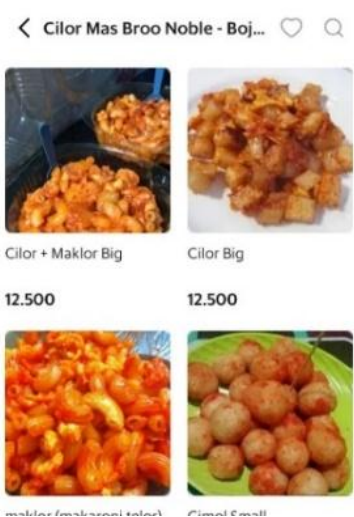

Gambar 2. Cilor Mas Broo Online

Yang beralih ke e-commerce dengan menggunakan Gojek atau Grab sebagai strategi pemasaran digitalnya. 


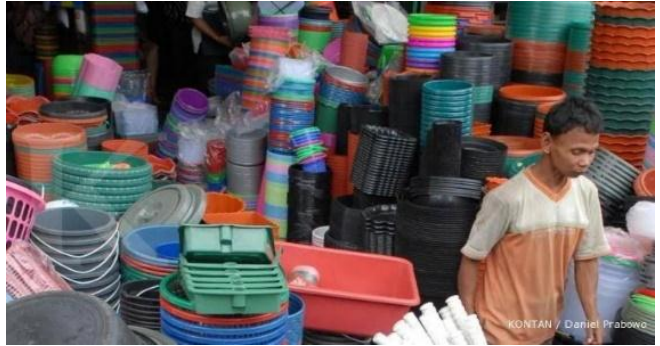

Gambar 3. Pedagang Parabot Offline

yang beralih ke e-commerce dengan pemasaran digitalnya.

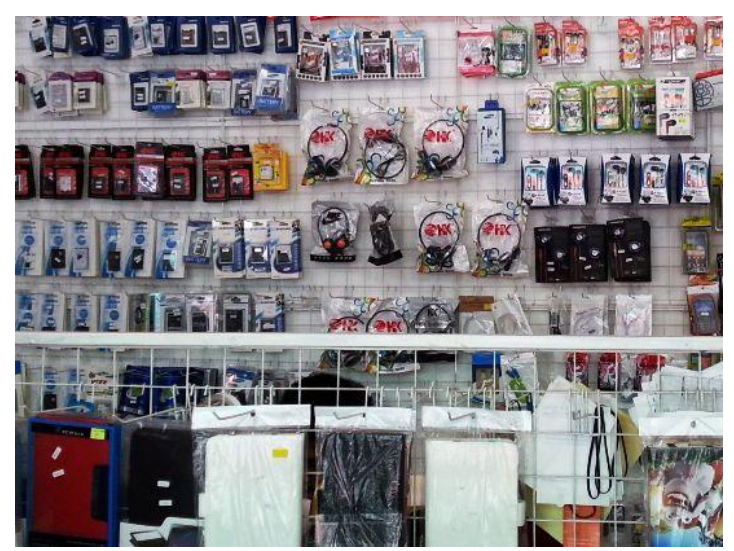

Gambar 5. Pedagang Case HP Offline yang beralih ke e-commerce dengan pemasaran digitalnya.

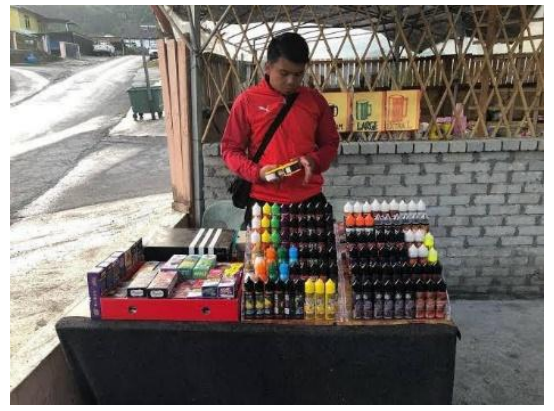

Gambar 6. Pedagang Vape Offline
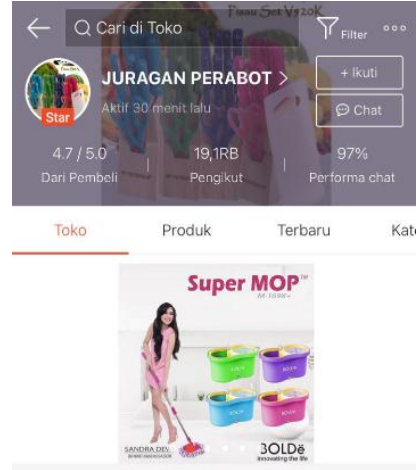

Gambar 4. Pedagang Parabot Online

menggunakan Shopee sebagai strategi

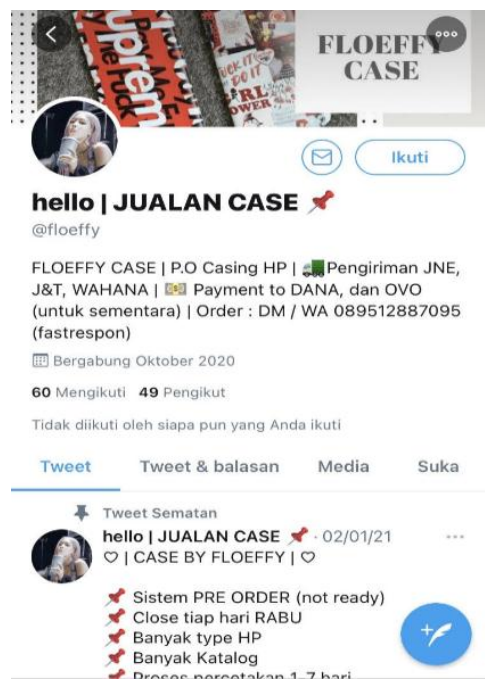

Gambar 6. Pedagang Case HP Online

menggunakan Twitter sebagai strategi
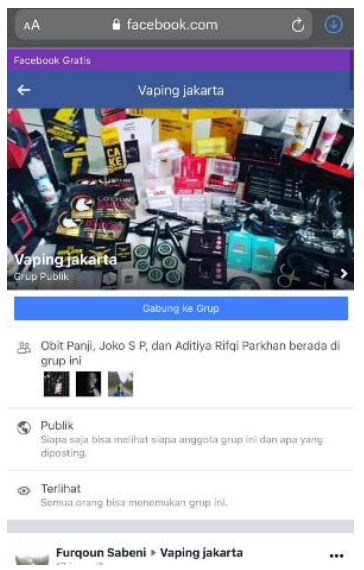

Gambar 8. Pedagang Vape Online 
yang beralih ke e-commerce dengan menggunakan Facebook sebagai strategi pemasaran digitalnya.

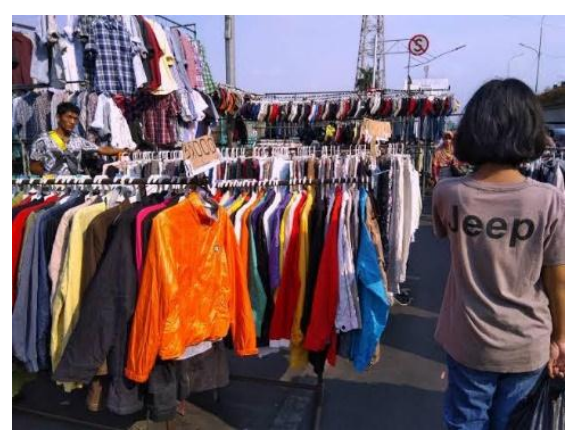

Gambar 9. Pedagang Thrift Offline

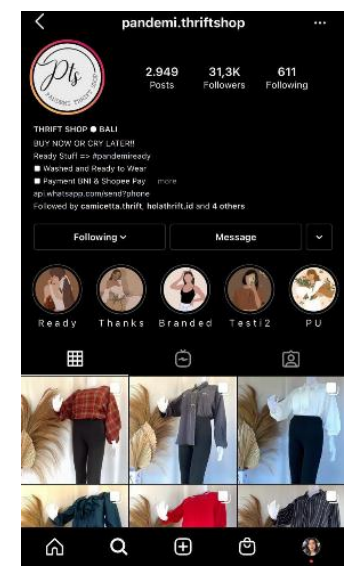

Gambar 10. Pedagang Thrift Online

yang beralih ke e-commerce dengan menggunakan Instagram sebagaistrategi pemasaran digitalnya.

Pemanfaatan internet dan media sosial sebagai bagian dari strategi pemasaran sudah sangat tepat apalagi di saat pandemi covid-19 ini. Hal ini tentunya memperkuat pendapat dari Suswanto \& Setiawati yang menyatakan bahwa pemasaran produk secara online sangatlah tepat dalam upaya mendukung pemasaran secara tradisional yaitu dengan menggunakan media sosial, antara lain, facebook, instagram, Whatsapp, telegram, serta tergabung dalam usaha online lainnya seperti shopee, go-food, dan grab-food [19]. Sejalan dengan hasil penelitian Yanmas UGM (2020) yang menyatakan bahwa selama pandemic Covid-19 media yang paling banyak dipakai adalah Whatsapp, instagram dan facebook.

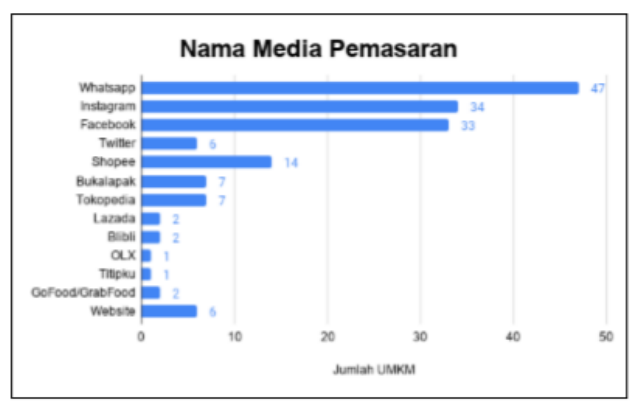

Gambar 11. Media Pemasaran yang paling banyak digunakan

Sedangkan jika merujuk pada kata yang dipublikasikan kata data (2020) transaksi e-commerce yang paling besar banyak terjadi di Facebook, whatsApps dan instagram

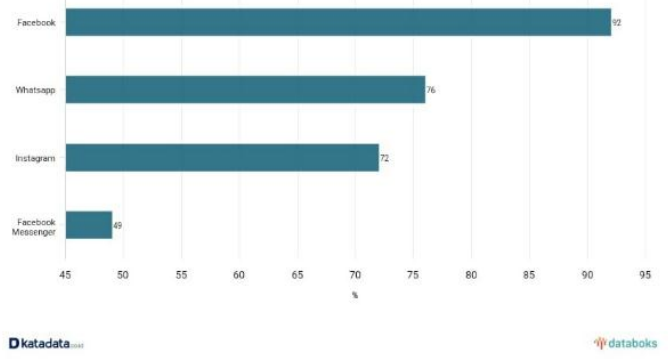




\section{Gambar 12. Data Transaksi E-Commerce Melalui Platform Media Sosial}

Oleh karena itu peluang bisnis dengan memanfaatkan media digital sangat besar bahkan akibat pandemic ini terjadi proses peningkatan media social dengan kecepatan tinggi diseluruh dunia. Berdasarkan penelitian yang dipublikasikan oleh katadata terlihat peningkatan dalam berbagai aspek terutama bisnis online, penjualan dan pembelian online selama pandemik.

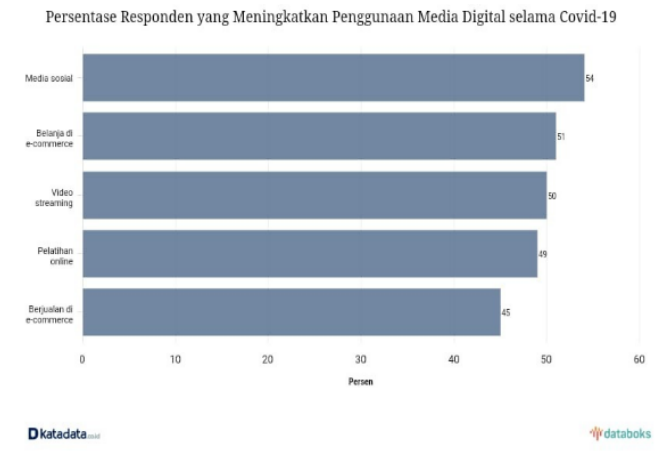

Gambar 13. Data Presentase Responden yang Meningkatkan Penggunaan Media Digital selama Covid-19.

\section{KESIMPULAN}

Dengan adanya virus covid-19 yang sudah menyebar luas ke seluruh dunia termasuk Indonesia berimbas pada permasalahan perekonomian Indonesia terutama UKM Sektor Informal Pedagang Kaki Lima. Pelaku Usaha Mikro dan Kecil sektor informal yang merasakan dampak signifikan dari pandemi Covid-19 adalah Pedagang Kaki Lima (PKL). Untuk mempertahankan kelangsungan usaha kecil (UMKM) pemanfaatan internet dan media sosial merupakan strategi yang sangat tepat di tengah pandemi covid-19 ini. Strategi bertahan yang digunakan UMKM diberbagai bidang termasuk Pedagang kaki lima di tengah pandemi covid-19 yaitu dengan menggunakan media sosial, antara lain, facebook, instagram, Whatsapp, telegram, serta tergabung dalam usaha online lainnya seperti shopee, go-food, dan grap-food.

Hasil ini sejalan dengan hasil penelitian terdahulu yang dilakukan oleh Susilo et, al., dan Avriyanti bahwa pemasaran produk dengan memanfaatan teknologi informasi melalui internet dan sosial media merupakan strategi yang tepat untuk memasarkan hasil produksi tanpa batas dengan tetap memperhatikan neraca keuangan perusahaan. Konsep tersebut semakin relevan dimasa pandemic.

\section{DAFTAR PUSTAKA}

[1] Budiyanti, E. (2020). Dampak virus corona terhadap sektor perdagangan dan pariwisata Indonesia. Info Singkat XII,(4).

[2] Sabariah, E. (2021). Strategi Mempertahankan Energi Dinamis Suatu Wirausaha Pada Perubahan Fenomena Khususnya Fenomena Pandemic Covid 19 Berbasis Pengetahuan. Jurnal Indonesia Sosial Sains, 2(1), 19-31.

[3] Hasanah, T. U., Nurhadi, N., \& Rahman, A. (2020). Modal Sosial dan Strategi Kelangsungan Usaha Sektor Informal Pedagang Kaki Lima pada Era Pandemi COVID-19. SOCIA: Jurnal IImu-IImu Sosial, 17(2). 
[4] Komara, B. D., Setiawan, H. C. B., \& Kurniawan, A. (2020). Jalan Terjal UMKM dan Pedagang Kecil Bertahan di Tengah Pandemi Covid-19 dan Ancaman Krisis Ekonomi Global. Jurnal Manajemen Bisnis, 17(3), 342-359.

[5] Nimpa, B. J. (2018). Strategi Pedagang Kaki Lima Di Kawasan Kuliner Pantai Tak Berombak (Ptb) Kecamatan Turikale Kabupaten Maros. Jurnal Environmental Science, 1(1).

[6] Firdaus, S. A., Ilham, I. F., Aqidah, L. P., Firdaus, S. A., Astuti, S. A. D., \& Buchori, I. (2020). Strategi UMKM untuk Meningkatkan Perekonomian selama Pandemi Covid-19 pada saat New Normal. OECONOMICUS Journal of Economics, 5(1), 46-62.

[7] Prasetya, A. (2020). PENGALAMAN PEKERJA INFORMAL DITENGAH PANDEMI COVID-19 DI KOTA BANDUNG. Jurnal Komunikasi, Masyarakat dan Keamanan, 2(2).

[8] Sasongko, D., Putri, I. R., Alfiani, V. N., Qiranti, S. D., Sari, R. S., \& Allafa, P. E. (2020). Digital Marketing Sebagai Strategi Pemasaran UMKM Makaroni Bajak Laut Kabupaten Temanggung. Jurnal Ilmiah Pangabdhi, 6(2), 92-96.

[9] Syaifullah, S., Maulana, A., Karnadi, V., \& Tantowi, R. (2020). PEMANFAATAN DIGITAL MARKETING BAGI USAHA MIKRO, KECIL DAN MENENGAH (UMKM) DI KECAMATAN BATU AJI KOTA BATAM. Jurnal Abdikmas, 1(1), 1-5.

[10] Susanto, B., Hadianto, A., Chariri, F. N., Rochman, M., Syaukani, M. M., \& Daniswara, A. A. (2021). Penggunaan Digital Marketing untuk Memperluas Pasar dan Meningkatkan Daya Saing UMKM. Community Empowerment, 6(1), 42-47.

[11] Jumhur, J. (2015). Model Pengembangan Pedagang Kaki Lima (PKL) Kuliner di Kota Singkawang. Jurnal Ekonomi Bisnis dan Kewirausahaan (JEBIK), 4(1), 125139.

[12] Sedyastuti, K. (2018). Analisis Pemberdayaan UMKM dan Peningkatan Daya Saing Dalam Kancah Pasar Global. INOBIS: Jurnal Inovasi Bisnis dan Manajemen Indonesia, 2(1), 117-127.

[13] Rohima, S. (2015). Entreprenuership dalam Pemberdayaan Diri Masyarakat Miskin. Jurnal Ekonomi Pembangunan, 13(1), 37-52.

[14] Rosmadi, M. L. N. (2021). Penerapan Strategi Bisnis di Masa Pandemi Covid-19. IKRA-ITH EKONOMIKA, 4(1), 122-127.

[15] Avriyanti, S. (2021). STRATEGI BERTAHAN BISNIS DI TENGAH PANDEMI COVID-19 DENGAN MEMANFAATKAN BISNIS DIGITAL (STUDI PADA UKM YANG TERDAFTAR PADA DINAS KOPERASI, USAHA KECIL DAN MENENGAH KABUPATEN TABALONG). Jurnal PubBis, 5(1), 60-74.

[16] Susilo, Y., Wijayanti, E., \& Santoso, S. (2021). PENERAPAN TEKNOLOGI DIGITAL PADA EKONOMI KREATIF PADA BISNIS MINUMAN BOBA. Jurnal Ekonomi Manajemen Sistem Informasi, 2(4), 457-468.

[17] Yatiningrum, A., Hendra, J., \& Saifullah, S. (2017). Analisis Pengaruh Pemberdayaan Wanita Pedagang Sektor Informal Terhadap Peningkatan Pendapatan Rumah Tangga. JURNAL MANAJEMEN DAN KEWIRAUSAHAAN, 5(2), 55-63.

[18] Suswanto, P., \& Setiawati, S. D. (2020). Strategi Komunikasi Pemasaran Shopee Dalam Membangun Positioning Di Tengah Pandemi Covid-19 Di Indonesia. LINIMASA: Jurnal IImu Komunikasi, 3(2), 16-29. 